\title{
PERFORMANCE BUDGETING AND MEDIUM-TERM FINANCIAL PLANING IN THE RUSSIAN FEDERATION
}

\author{
ALEKSEI G. PAUL ${ }^{1}$
}

\begin{abstract}
Last decades budget expenditure planning in the Russian Federation transferred from line-item budgeting to performance budgeting. The basis of multiannual financial planning was laid in the Russian Federation by the Concept of budget process reforming in the Russian Federation in 2004-2006 approved by the Government of the Russian Federation Budget Code provides budgeting for next fiscal year and a two-year planned period. However, the process of transition was hard. Russian authorities had to use the international experience of budget planning. So the aim of the paper to discover some approaches to performance budgeting with help of comparative legal studies.
\end{abstract}

\section{Keywords}

Performance budgeting; medium-term financial planning; budget expenditure; objective program

\section{JEL Classification: D63, H69, K39}

\section{Introduction}

Last decades budget expenditure planning in the Russian Federation transferred from line-item budgeting to performance budgeting. Budget Code provides budgeting for next fiscal year and a two-year planned period. However, the process

1 Associate Professor of Financial Law Department, Faculty of Law, Voronezh State University, Voronezh, the Russian Federation. The Author specializes in budget law and tax law. The author of 3 books and the coauthor of 7 textbooks. He presented his scientific research in 17 reviewed articles in prestigious journals and in more than 70 another journals and conference proceedings. He is a member of the Information and Organization Centre for the Research on the Public Finances and Tax Law in the Countries of Central and Eastern Europe. Contact email: pag@law.vsu.ru. 
of transition was hard. Russian authorities had to use the international experience of budget planning. So the aim of the paper to discover some approaches to performance budgeting with help of comparative legal studies.

\section{Performance Budgeting in Medium-Term Financial Planning}

The basis of multiannual financial planning was laid in the Russian Federation by the Concept of budget process reforming in the Russian Federation in 2004-2006 approved by the Government of the Russian Federation (Act no. 249/2004). Earlier in the post-Soviet period, budget planning had other approaches. By the beginning of the reform, Russian budget law provided for neither multiannual budget planning nor estimation of budget expenditure results. There were the next problems:

a) the mid-term financial plans were developed for annual budget cycle only; budget expenditures were planned just for next year. The budget legislation did not define sums and structure of budget appropriations allocated to budget administrators,

b) the budget expenditures were calculated by adjusting (indexing) of recent year expenditures. Budget Code of the Russian Federation did not prescribe mechanisms of budget resource redistribution. We did not have clear criteria and procedures for selection of funded directions in accordance with the priorities of state policy,

c) there was no clear formulation of budget expenditure objectives as well as criteria for estimating of budget administrator results.

The main purpose of the conception was the introduction of conditions for the most efficient management of the state (municipal) funds in accordance with the priorities of state policy. The essence of the reform was to shift the budget process from "management of budgetary resources (expenditures)" to "management of results"; to enhance responsibility and to expand the independence of budget administrators in the framework of medium-term objectives.

Russian authorities offered the following directions of the reform:

a) to reform the budget classification of the Russian Federation and the fiscal accounting in accordance with international financial reporting standards,

b) to divide budget into existing obligations and accepting (new) obligations,

c) to improve medium-term financial planning,

d) to introduce performance budgeting,

e) to streamline procedures for drafting and adopting of law on budget. 
The core of the new organization of the budget process should be the concept of "performance budgeting in the medium-term financial planning" widely used in the world. In other words, the main purpose was to increase the horizon of financial planning and to introduce program-objective methods of budget planning.

Some guidelines of the reform were based on the international experience of budget reforms. According to the Russian financial authorities, a number of budgetary and legal institutions were affected by international standards adopted by the International Monetary Fund, the World Bank and the Organization for Economic Co-operation and Development (Artukhin, 2012). In relation to the introduction of multi-annual financial planning and performance budgeting, the Concept stated that one of the main elements of budget reforms undertaken in the last decade in most developed countries was the transition to medium-term budget planning. A budget cycle begins with a review of previously approved in the previous budget cycle main parameters of the medium-term financial plan, with analysis of changes in external factors and conditions, with substantiation of changes in the main budget indicators of the planned year as well as updating the budgetary projections for the next years of the forecasting period.

The Authors of the reform proposed introducing of mentioned approach into the Russian practice of budget planning. The budget for the next fiscal year should become a part of the mid-term (three years) plan that was annually updated. On the one hand, this system ensures the continuity of the state policy and predictability of budget allocations; on the other hand, it allows making transparent annual adjustments in accordance with the policy objectives and the conditions of their achievements.

\section{Stages of Reforms}

The purposes of the reform were implemented in stages. Firstly, Russian authorities started the transition to the multiannual budget. The Federal budget for 2006 became the first budget formed within the three-year financial plan. It was the basis for the drafting of fiscal policy for the next three-year budget.

The budget legislation provided for the transition to drawing up a three-year budget in 2007 when the Parliament of the Russian Federation amended the Budget Code. The amendments to the Budget Code of the Russian Federation provided for the annual drafting and adopting of the federal budget for 3 years (the next financial year and two-year planned period). That rules should ensure continuity and predictability of fiscal policy, contribute to the sustainability of the budget system of the Russian Federation, improve the reliability of budget expenditures, and make 
the state contracts for 3 years or for the whole period of implementation of the longterm objective programs (investment projects).

The basis of budget planning consisted of the method of "sliding three-year budgeting". In such conditions, earlier adopted budget expenditures for second and third years of the three-year period become the basis of the next year budget. Actually, the Russian budget legislation reflected provisions adopted in Art. 9 of the Council of the European Union Directive 2011/85/EU of 8 November 2011 on requirements for budgetary frameworks of the Member States that prescribes providing for the adoption of a fiscal planning horizon of at least 3 years.

Adopting projections for second and third years of the planned period did not mean a ban on their adjustment in the next budget cycle. However, these changes should not worsen the position of the main budget administrators and recipients of budgetary transfers. These provisions of Russian budget legislation meet Art. 9/2b of the Directive 2011/85/EU prescribed that medium-term budgetary frameworks shall include procedures for establishing of projections of each major expenditure and revenue item of the general government for the budget year and beyond, based on unchanged policies.

Thus, the "sliding three-year budgeting" ensures, on the one hand, the stability and predictability of the budgetary projections and, on the other hand, the possibility of their amending in case of changes, restructuring expenditures, the implementation of new priorities of the budget policy. In order to increase budget sustainability, the Budget Code introduced "conditionally adopted expenditures" (5\% of the total expenditures) that not distributed among main budget administrators and articles of budget classification for the planned period (second and third year of the three-year period). These rules allowed to create a reserve in case of an unexpected decline of incomes or to use the "conditionally adopted expenditures" for making new obligations in the next budget cycle.

Mentioned budget rules about "sliding three-year budgeting" were indispensable just for the federal budget. Regional and local authorities of the Russian Federation have the choice between adopting of their budgets for 3 years or for the next financial year (with the drafting of the mid-term financial plan).

\section{Implementation of Reforms}

Implementation of the performance budgeting was more problematic. Earlier Russian budget legislation provided for line-item budgeting. Financial authorities drafted budgets by indexing of previous year budget expenditures. There were 
no estimations of budget expenditure effects. Because of the reform, the main instruments of budget planning should be federal objective programs and departmental objective programs.

The federal objective programs had an inter-sectoral nature. They should be adopted by the Government of the Russian Federation and include a large investment, scientific-technical and (or) structural projects requiring a long period of realization. The departmental objective programs are intra-sectoral. They are adopted by special executive authorities. The Budget Code of the Russian Federation provided for these types of programs. They were used in the budget planning. However, currently, the federal objective program was renamed into the state program of the Russian Federation.

Nowadays the state programs should, in particular, contain the objections and priorities of the state policy; the list and characteristics of the main activities to achieve the state program objections with timelines for their implementation and expected results; the main measures of the legal regulation aimed at achieving the objections and (or) the expected results of the state program; the information about the objection indicators of the state program broken down by years of its implementation, information about financial provision of the state program funded by the federal budget (details by the main budget administrators, by federal objection programs and by the years of the state program implementation).

By present time, the Government of the Russian Federation has adopted the Procedure for development, implementation and estimation of effectiveness for state programs of the Russian Federation (Act no. 588/2010), the list of state programs of the Russian Federation (Act no. 1950-R/2010). The Ministry of Economic Development has approved the Methodological recommendations for the development and implementation of state programs of the Russian Federation (Act no. 582/2016). Now we have 42 state programs of the Russian Federation.

The law on the federal budget for 2014 and for planning period of 2015 and 2016 became the first budget approved in the context of state programs. It contained an exhibit that breaks down expenditures by state programs. Nowadays performance budgeting is implemented at the regional level with the methodical support of the Ministry of Finance. Despite the gradual implementation of multi-annual financial planning and performance budgeting in Russian budget law, the reforms are continuing.

The President of the Russian Federation drew attention to the fact that the planning of socio-economic development and budget planning still remain insufficiently coordinated. The tasks of socio-economic policy and the results of their implementation are still considered separately from the budget policy. There is no 
clear system for estimating of budget expenditure effectiveness. The state programs did not become means for the formulation and implementation of state policy in long term. Many programs demand to increase budgetary financing without identifying financial sources. Some programs have been adopted in several variants that differ both on planned results and on amounts of funding. The task of transition to longterm budget planning is not solved. The Government of the Russian Federation has not approved long-term budget strategy that should determine the cost framework of the state programs in connection with the forecast of the main budget parameters (Act no. 13/07/2013, on budget policy in 2014-2016).

The Program of the Government of the Russian Federation on increase of budgetary expenditures efficiency for the period until 2012 (Act no. 1101-R/2010, on Program of the Government of the Russian Federation on increase of budgetary expenditures efficiency for the period until 2012) drew attention to the fact that strategic planning remained to be poorly linked with budget planning. In this regard, one of the main tasks was to draft mechanisms aimed at ensuring better integration of strategic and budget planning as well as at monitoring of achieved stated objectives. Actually, in the Program, Russian authorities took into account the provisions of documents adopted by international organizations. For example, according to the Art. 2/1/2 of the Code of good practices on fiscal transparency (Act of the International Monetary Fund, 2007) the annual budget should be realistic and should be prepared and presented within a comprehensive medium-term macroeconomic and fiscal policy framework. Fiscal targets and any fiscal rules should be clearly stated and explained. In fact, these tasks were prescribed by the mentioned Program.

Last year the Government of the Russian Federation adopted the Program for an increase of public (state and municipal) finances management efficiency for the period until 2018 (Act no. 2593-R/2013). The Program shows some unsolved problems in budget planning, including:

- the absence of regulated procedures for drafting, studying and using of socio-economic development forecasts in the budgetary process and in the drafting of state strategic planning documents;

- despite the program structure of the federal budget for the year 2014 and for the planning period 2015 and 2016, the Government of the Russian Federation did not take into account achievement of state program objectives in the planning of budget appropriations;

- the issues of state program efficiency are not essential in the drafting of the federal budget:

- the absence of an integral system of strategic planning and weak linkage between the strategic and budget planning; 
- the uncertain relations and lack of coordination between various objective program means;

- the incompleteness of formation and limited practice of state (municipal) programs as the main instrument to achieve the objectives of the public (municipal) policy as well as the basis for budget planning.

The Program suggests the following solutions:

- to define all directions of the state (municipal) policy only in the framework of state (municipal) programs. At the same time, strategic planning documents should define the main directions of the policy as well as requirements for the state (municipal) programs;

- to draft the Budgetary strategy of the Russian Federation for the period until 2030 that should determine budget expenditures for the state programs on the basis of main budget parameter forecast. The President of the Russian Federation prescribes to the Government of the Russian Federation to complete the development of the budgetary strategy of the Russian Federation for the period up to 2030 in a short time as well as to amend the long-term forecast of socio-economic development if it is necessary (Act no. 13/07/2013, on budget policy in 2014-2016). This suggestion meets the requirements of Art. 9/3 of the Directive 2011/85/EU that demands so that projections adopted within medium-term budgetary frameworks shall be based on realistic macroeconomic and budgetary forecasts.

Russian scientists express the same opinion. They say that the problems related to the performance budgeting due to the objectives of budget expenditures are formulated outside the budget process in the course of budget administrator activity. In addition, detailed plans of economic and socio-economic development (national economic plans) (three years, five years, and others) are not published.

The mechanism of drawing up such plans in the Russian Federation was lost with the dissolution of USSR and the State Planning Committee of the USSR (Komyagin, 2011). By now, the Ministry of Economic development of the Russian Federation has adopted the Forecast of long-term socio-economic development of the Russian Federation for the period until 2030. Based on this document in accordance with the requirements of the Budget Code of the Russian Federation the Ministry of Economic development drafts a forecast of socio-economic development of the Russian Federation for the next financial year and two-year planning period. In its turn, this forecast is the economic basis for drafting a budget for the next financial year and two-year planning period. In addition, the Government of the Russian Federation has adopted the Concept of long-term socio-economic development of the Russian Federation for the period until 2020 (Act no. 1662-R/2008). 


\section{Conclusions}

The last decade the Russian Federation made serious steps in the transition to medium-term financial planning on the basis of performance budgeting. The federal budget is adopted for the next financial year and two-year planning period with breaking down by state programs. At the same time, there are problems related to the correlation between mid-term financial planning and socio-economic planning, to the estimation of program implementation. These problems should be solved by continuing reforms in the field of the financial sector.

\section{References}

Artukhin, R.: Вопросы развития бюджетного права (Issues of budget law development), Pеформы и право (Reforms and law) no. 3 (2012).

Komyagin, D.: Бюджетное право России (The Budget Law of the Russian Federation), Moscow: The Institution of public law research, 2011.

EU: Directive no. 2011/85/EU, on requirements for budgetary frameworks of the Member States.

RU: Act no. 1101-R/2010, on Program of the Government of the Russian Federation on increase of budgetary expenditures efficiency for the period until 2012.

RU: Act no. 13/07/2013, on budget policy in 2014-2016.

RU: Act no. 1662-R/2008, on Concept of long-term socio-economic development of the Russian Federation for the period until 2020, as amended.

RU: Act no. 1950-R/2010, on List of state programs of the Russian Federation.

RU: Act no. 249/2004, the Concept of budget process reforming in the Russian Federation in 20042006, as amended.

RU: Act no. 2593-R/2013, on Program for the increase of public (state and municipal) finances management efficiency for the period until 2018.

RU: Act no. 582/2016, on methodological recommendations for the development and implementation of state programs of the Russian Federation.

RU: Act no. 588/2010, on Procedure for development, implementation and estimation of effectiveness for state programs of the Russian Federation.

RU: Act of the International Monetary Fund, 2007, on Code of good practices on fiscal transparency. 